\title{
Mobbing in the Public Sector: the Case of the Ministry of National Defence of Lithuania and its Institutions
}

\author{
Nijolė Skurdenienè \\ General Jonas Žemaitis Military Academy of Lithuania \\ Šilo g. 5a, LT-10322 Vilnius, Lithuania \\ Dalia Prakapienè \\ General Jonas Žemaitis Military Academy of Lithuania \\ Šilo g. 5a, LT-10322 Vilnius, Lithuania \\ cross $^{\text {ref }}$ http://dx.doi.org/10.5755/j01.ppaa.20.1.28862
}

\begin{abstract}
One element of any organization's success is its organizational culture that manifests itself through the creation of a value system and emphasis on the well-being of employees. In this context, mobbing is a phenomenon understood as psychological stress experienced by individuals at work as a result of certain actions by another person leading to negative consequences for the individual, the organization and society. Given the fact that mobbing in statutory organizations or in organisations involved in their activities has hardly been studied, this article aims to reveal the peculiarities of mobbing in the Ministry of National Defence of Lithuania and its institutions through the organizational environment and employees' relationships. Two hundred and one participants responded to the questionnaire. It was found that mobbing exists in the Ministry of National Defence and its institutions, but the number of employees experiencing workplace bullying corresponds to the general trend established by scientific research. The results also revealed that mobbing does not depend on the employee's length of service, it is most commonly expressed through verbal communication and women experience it more often than men. It can be stated that the prevention of mobbing in the institutions under analysis is very weak and conflicts are solved in a time-consuming manner, concentrating only on local measures.
\end{abstract}

Keywords: mobbing, employees' relationships in organisation, the Ministry of National Defence of Lithuania, causes of mobbing, prevention of mobbing

Raktažodžiai: mobingas, darbuotoju santykiai organizacijoje, Krašto apsaugos ministerija, mobingo priežastys, mobingo prevencija

\section{Introduction}

Management scholars often discuss issues of the organizational culture, employee welfare development and the functioning of organizational value systems. In the context of these discussions, certain problems often emerge in relation to the problems within organizations, such as stress, harassment or violence in the workplace. Scientific literature (Guglielmi et al., 208, Feijó et al., 2019) usually attributes them to the phenomenon of mobbing which is analysed through separate aspects of causes and consequences. This issue is very often explored by organizational behavioural psychologists (Hassard, 2018; Akter, 2019; Góralewska-Słońska, 2019; Galletta, 2019) and is studied to a lesser extent from the perspective of classical management research (Guglielmi, 2018; Mujtaba, Senathip, 2020; Vveinhardt et al., 2020). However, the managerial perspective is particularly relevant because research shows that damage caused by mobbing is systemic, affecting not only the individual, but also the entire organization. This leads to a decrease in the quality of work and work efficiency, an increase in staff turnover and, as a result, in the costs of finding new employees and their training, etc. Even though mobbing research has been carried out in Lithuania (Vveinhardt, Žukauskas (2010), 
Pajarskienè et al. (2012), Astrauskaitè (2013), etc.), mobbing in the institutions of the National Defence System (hereinafter - NDS) has been poorly researched. Likewise, such studies in other countries are very rare and fragmentary due to the peculiarities of the system. Nevertheless, it is important to know whether employees in the institutions of the NDS experience mobbing; if so, then to what extent and whether mobbing occurs only exclusively in certain groups with certain common social and demographic characteristics, etc. The choice of the problem and field of research were based on Leymann's (1996, p.175) mobbing activities, which were classified into five categories depending on the effects the activities have on the victims (effects on the victims' possibilities to communicate adequately, possibilities to maintain social contacts, to maintain their personal reputation, occupational situations and physical health).

The research object was the manifestation of mobbing in the Ministry of National Defence of Lithuania (hereinafter - MND) and its institutions. The aim of the article was to reveal its peculiarities through the organizational environment and employees' relationships. Based on the findings presented in management research, the following hypotheses were made: mobbing experienced by employees in communication is directly related to the isolation in the team (H1); it is directly related to their reputation $(\mathrm{H} 2)$; it is directly related to the assignment of tasks to these employees $(\mathrm{H} 3)$; mobbing experienced by employees while excluding them from the team is directly related to the attack on their reputation (H4); it is directly related to the tasks assigned to them (H5); mobbing experienced by employees during a reputation attack is directly related to the tasks assigned to them (H6); it is directly related to the harm suffered by them (H7); mobbing experienced by employees through the assignment of inappropriate, offensive tasks is directly related to their health (H8); the frequency of mobbing depends on the gender (H9); mobbing depends on the length of service (H10).

The research was modelled using the basic provisions and principles of the quantitative research methodology (Bryman, 2016). The data were collected using the questionnaire survey method and were processed using statistical analysis methods. The survey was conducted in AprilMay 2019. The research involved 201 participants working in the MND and its institutions. Participation in the study was voluntary. The study was conducted following the basic ethical principles of quantitative research.

\section{Theoretical assumptions of mobbing research}

Misconduct in the workplace is a broad concept which includes abuse and insults, discrimination and disrespectful behaviour that employees may experience at work. Two terms, i.e., mobbing and bullying, are used in scientific literature to describe this phenomenon. Some researchers, when analysing the phenomenon of mobbing, distinguish its essential features: stress experienced by one or more individuals, an intimidating environment, constant threat (Vveinhardt, Žukauskas, 2010), gossip, verbal and non-verbal actions (Salin et al. al., 2019), discrimination expressed through power relations (Vveinhardt, 2011; Duffy and Sperry, 2014), bullying, professional humiliation and harm, deliberate misinformation, intimidation, social exclusion (Mileta, 2012), the need to ridicule, humiliate and remove the victim from the organization (Vveinhardt and Žukauskas, 2012). Mobbing is often experienced as an intense, regular and long-lasting phenomenon that can last indefinitely with varying frequency (e.g., once a week for about a year, each day for six months) (Astrauskaite and Kern, 2013), followed by consequences for the individual, the organization and society (Vveinhardt, 2011; Georgakopoulos and Kelly, 2017; Guglielmi, 2018). For instance, it compromises employees' psychological and physical health (Nielsen et al., 2015; Notelaers et al., 2018), affects the organizational climate (Samnani and Singh, 2016, Guglielmi, 2018), reduces productivity and profits while society has to take care of a laid-off worker and, instead of increased budget revenues (derived from taxes paid by the employee), incurs health and social security costs (Sperry and Duffy, 2009).

As for the causes of mobbing, researchers attribute them to many factors: a poor social organizational climate (Samnani and Singh, 2016), personality traits of abusers and victims (Nielsen et al., 2017), poor leadership (Zaitseva and Chaudat, 2016), ethical crises in the organization (Vveinhardt, 2012; Kowal et al., 2020), psychosocial factors at work and poor conflict management 
traditions (Vveinhardt and Žukauskas, 2012). Interpretations of the causes of mobbing described in the literature can help to distinguish certain levels: at the organizational level, mobbing is caused by power imbalances (Zapf and Einarsen, 2011, p. 10), a bad organizational climate, stress, organizational problems (Vveinhardt, 2018), heavy workload, stressful psychosocial working conditions (Spagnoli and Balducci, 2017), leadership quality, lack of both responsibility for intolerable actions and sanctions for conflict escalation (Vveinhardt 2010, p. 144). At the individual level, however, mobbing is the result of the tension between employees (unhealthy competition, jealousy, revenge, hatred, etc.) (Leymann, 1996, Vveinhardt and Žukauskas, 2012) and personality traits (the victim's sensitivity, caution, poorer ability to confront the abuser and a greater need for recognition) (Nielsen et al., 2017). Finally, at the social level, mobbing can exist as a result of insufficient conflict management skills, well-established traditions and relationships, low managerial competencies of the management and nepotism (Prakapienè and Skurdeniené, 2019; Sroka, Vveinhardt, 2020).

In conclusion, mobbing is said to be intense and regular psychological stress experienced by one or more individuals at work due to negative actions by another person leading to negative consequences for the person, the organization, and society. It affects employees' well-being, causes stress as well as reduces productivity and the quality of operations, etc. Therefore, managers of the organization must first understand problems caused by mobbing, identify them publicly and choose the most appropriate model for the prevention mobbing and intervention.

\section{Methodology}

\section{Research methods}

The methodology of quantitative research and the classical questionnaire survey method were chosen to achieve the research aim and to collect the research data, respectively. The existence of a methodology-based and validated research tool (Vveinhardt and Streimikienè, 2015) to measure the problems of the research was the key factor in the choice of research methodology. Research data (which were processed with SPSS 20.0 software) and hypotheses were tested using statistical methods (Čekanavičius, Murauskas, 2014) such as frequencies, scattering measures, Pearson correlation coefficient (r), Pearson's chi-squared test $\left(\chi^{2}\right)$. The magnitude of the correlation coefficient was assessed using the given levels of the correlation strength (from 0 to 0.2 - there is essentially no relationship between the features, from 0.2 to 0.4 - the relationship is weak, from 0.4 to 0.6 - the relationship is essential, 0.6 to 0.8 - the relationship is strong, 0.8 to 1 - the relationship is very strong). The level of significance $\mathrm{p}<0.05$ was chosen for the data analysis. In addition, the Cronbach's alpha test $(\alpha)$ was used to check the internal consistency of the used scales. Finally, a linear regression analysis was performed to predict the possibilities of mobbing prevention (Bekešienè, 2015, p.165).

\section{Research instrument}

The validated questionnaire "Mobbing and Single Cases of Harassment in Employees' Relations (MSCH)" from Vveinhardt and Streimikiene (2015, p. 441-466) was used, after adapting the questions to the employees of the MND. This universal questionnaire consists of 20 questions and 47 items (Likert scales) and was developed to identify the type of bullying victims experienced in a management context. 8 out of 20 questions were demographic in nature to form portraits of mobbing victims while the remaining 12 questions sought to determine the duration and the frequency of harassment, the reaction of the victim and who provided help, measures to stop the harassment, consequences for the abuser, etc. Three scales were used in the study: (1) communication failures among employees $(\alpha=0.981)$; (2) the formation of a negative opinion and the nature of work ( $\alpha=0.986)$; (3) employees' physical condition and consequences $(\alpha=0.965)$.

\section{Research sample}

Respondents were selected according to a simple random sampling method. The selection was carried out using criterion selection where a necessary criterion for the research participants was to 
work at the MND or its institutions while an additional criterion was to represent different age and gender groups. The number of respondents was determined by using Yadav's sample calculation formula (Kardelis, 2016). At the time of the research, the general sample size was 420; therefore, it was calculated that the sample size should be at least 201 respondents in order to achieve $95 \%$ reliability characteristic of social science research. Thus, 39 soldiers of professional military service and 162 civil servants and employees working under an employment contract were selected for the research.

\section{Research ethics and limitations}

The study followed the basic principles of research ethics (Bryman, 2016, p. 136-137). Respondents were introduced to the principles, the purpose of the study, the definition of mobbing as well as the possibility to terminate the research at any time. It was explained that the study was quantitative and all the data would be statistically summarized, thus ensuring the anonymity of all the participants. Due to the peculiarities of the activities in the MND and its institutions, a formal permit for the research had to be obtained. The limitations of the study were related to a relatively small general sample, which could have led to statistically larger deviations. This problem could have been solved by choosing another sampling method (e.g., stratified sampling), but due to the abovementioned peculiarities of the activities, it was very difficult to do so. Another limitation of the research was related to the fact that even though formally the majority of employees in these institutions are civilians, in reality, soldiers comprise the largest proportion (some of whom serve for a short period of time only). Future research could focus exclusively on soldiers (professional ones and conscripts), using the same validated scales of research instruments.

\section{Findings}

$80.6 \%$ of the respondents did not perform any managerial functions at the time of the research; $67.7 \%$ were civilian employees; $74.6 \%$ were married. The vast majority (93\%) had obtained a degree in higher education. Women represented just over half $(53.7 \%)$ of all respondents. The presented general data basically correspond with the real proportions of employees of the institutions belonging to the MND at the time of the research; therefore, it can be stated that a common respondent is a welleducated married employee of the NDS who does not perform any leadership functions.

\section{General characteristics of mobbing, its prevention and intervention}

The aim of the questionnaire survey was to determine the proportion of respondents who had experienced bullying and harassment at work and to find those who had experienced misconduct to identify mobbing and measures to prevent it. The results showed that $23.4 \%$ of the respondents had experienced bullying and harassment in the last two years. These numbers are in line with those of other studies conducted in Lithuania in various institutions of public administration (e.g., Pajarskienè et al., 2012, Vveinhardt and Andriukaitienè, 2015, Balčiūnienė and Rumšaitė, 2016).

The analysis of answers was carried out to determine the nature of harassment, i.e. horizontal, vertical or horizontal and vertical. The following types were distinguished: horizontal (one employee against another one), horizontal (several colleagues against one employee), vertical (the manager against his/her subordinate or vice versa), and horizontal and vertical (both the manager and the colleagues). Results showed that 54\% of the respondents had experienced mobbing from one or more colleagues (horizontal), 34\% had experienced it from managers, while 17\% had experienced it from colleagues and managers. Therefore, it can be assumed that the MND is dominated by horizontal mobbing.

As for the reaction to misconduct, it was found that $46.1 \%$ of the respondents who had experienced mobbing told their relatives and colleagues about it, $15.7 \%$ reported misconduct to the manager and $12.4 \%$ did not react while the same number of respondents asked the abuser to stop. It should be noted that only one research participant had sought psychological help. Obviously, external help from specialists is rarely sought and most often the solution to the problem is limited to 
conversations with relatives and colleagues. The research data showed that the respondents had received support or help from the latter $(61.9 \%$ from relatives, $27 \%$ from colleagues, $9.5 \%$ from managers). Irrespective of whether help was provided or not, $63.8 \%$ of the respondents stated that the organization had not taken any action to avoid bullying or harassment while $21.3 \%$ did not know whether any steps had been taken to avoid them in the future. It can therefore be assumed that there are communication problems in the organization.

With respect to the actions taken against the abuser, 55.6\% of the respondents stated that there had been none. According to them, verbal warning $(16.7 \%)$ had been the only measure taken by managers against the abuser. In $47.1 \%$ cases, managers had discussed the situation with colleagues; however, $41.2 \%$ of the respondents felt that no action had been taken. Thus, managers/the organization are thought to avoid acknowledging the problem of mobbing in the organization publicly; therefore, conflict resolution is limited to talking to colleagues. All this shows that conflicts in the MND are solved reluctantly (most often without taking any action), focusing on local measures (e.g., discussions with colleagues).

\section{Testing hypotheses and research results}

The strength of the relationship between individual subscales in the instrument scales was examined to test the hypotheses (see Figure 1). The statistical analysis of the data showed that there was a moderate or in some isolated cases a weak correlation between the following subscales: communication and isolation $(r=0.476 ; p<0.001)$, reputation $(r=0.474 ; p<0.001)$ and assignments $(\mathrm{r}=0.315 ; \mathrm{p}<0.03)$; between isolation and reputation $(\mathrm{r}=0.490 ; \mathrm{p}<0.001)$ and assignments $(\mathrm{r}=0.354$; $\mathrm{p}<0.02)$; between reputation and assignments $(\mathrm{r}=0.425 ; \mathrm{p}<0.01)$ and harm $(\mathrm{r}=0.343 ; \mathrm{p}<0.02)$; between assignments and health $(\mathrm{r}=0.487 ; \mathrm{p}<0.001)$.

Statistically significant weak or moderate linear positive relationships indicated that the victims had experienced greater isolation, greater reputation attack and greater misconduct through the assigned tasks. In addition, the research data showed that negative effects on the health of victims were ultimately increasing. These results were also confirmed by Leymann (1996) and Notelaers et al. (2018).

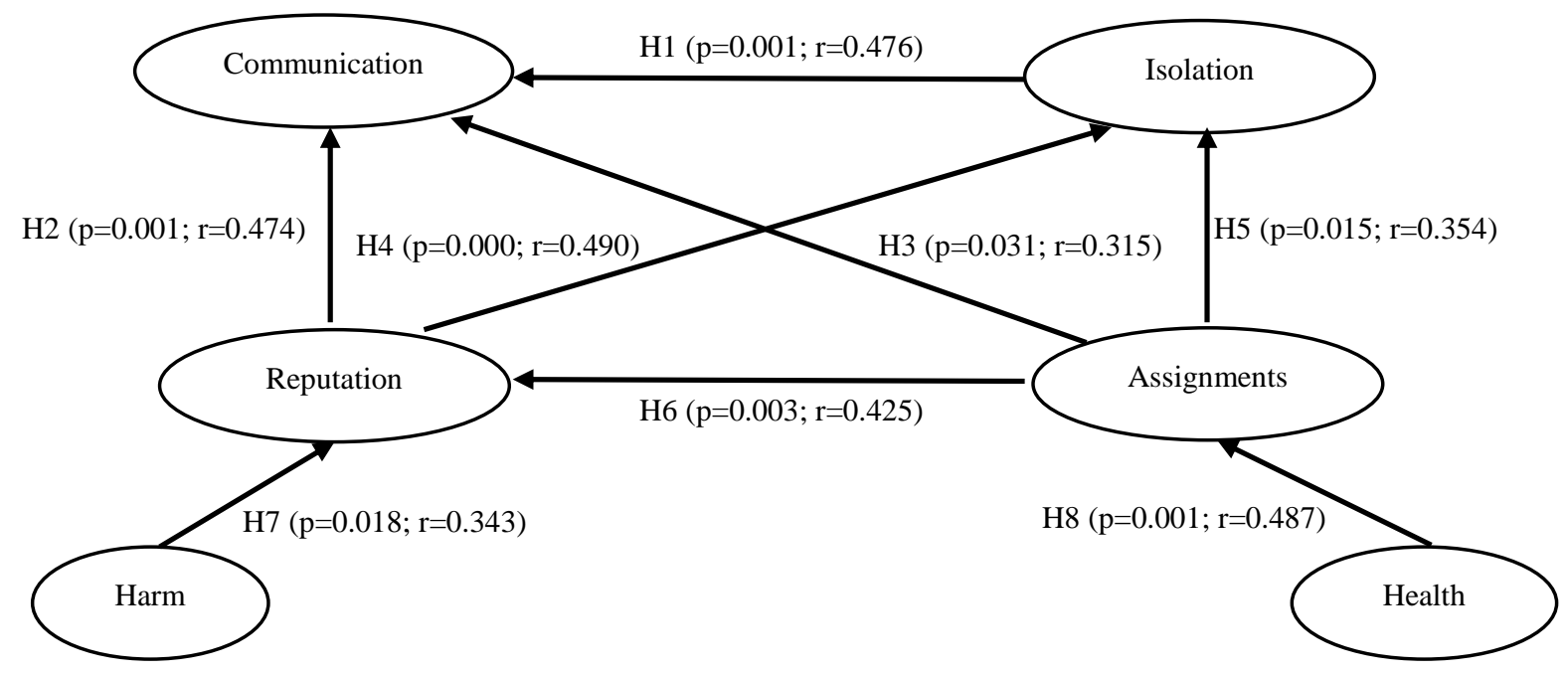

Fig.1. A Relationship Matrix for Employees Experiencing Mobbing Source: Authors.

The aim of the data analysis was to check whether there were any links between mobbing and gender. The $\chi 2$ test showed that $76.6 \%$ of the female respondents and only $23.4 \%$ of the male ones had experienced mobbing. Given the sample sizes of both genders, it is evident that a significantly higher proportion of women experience workplace bullying in the MND and its institutions. The statistical analysis shows that this is not a coincidence $(\chi 2=12.900 ; \mathrm{df}=1 ; \mathrm{p}<0.001)$, i.e., mobbing is 
related to the gender of the respondent. However, while analysing data from other studies from the perspective of gender, no consensus on this issue could be established. For example, Takaki et al. (2010) did not find a link between mobbing and gender and later studies (Salin, 2015; Zachariadou et al., 2018; Akter, 2019; Góralewska-Słońska, 2019) show that gender was found to be significant in mobbing cases, i.e., men were less likely to experience mobbing than women.

The analysis of the data using a nonparametric test to find a link between the frequency of mobbing and the length of service found that there was no statistical correlation ( $p>0.05)$ and work experience did not play an important role in mobbing cases in the MND and its institutions. However, studies by other researchers on this subject suggest that a statistically significant relationship exists. For example, Vveinhardt and Žukauskas (2012) state that respondents with 4-7 years of experience are more likely to experience mobbing while, according to Zachariadou et al. (2018), it is those who have worked in the organization for 6 or 10 years. Thus, it can be said that the formation of the management culture while developing the NDS of independent Lithuania was rather successful and the preventive measures were taken at an early stage of the development to prevent misconduct between young and older employees.

Preventing mobbing in the MND. A linear regression analysis of the research data was performed to predict the possibilities of the prevention of mobbing. Two variables, i.e., communication failures among employees (the dependent variable) and the formation of a negative opinion and the nature of work (the independent variable), were chosen for analysis. The former variable was formed from the communication and isolation subscale blocks which consisted of 16 elements $(\alpha=0.981)$. The latter formed from the reputation and assignments subscale blocks $(\mathrm{N}=23)$ was found to be highly reliable $(\alpha=0.986)$. Before starting the analysis, distributions and their compliance with the criteria of the normal distribution were checked (Pakalniškienè, 2012). According to the Shapiro-Wilk criterion, communication failures in the samples of men and women showed that the coefficients fell within the limits of the normal distribution and there were no differences in the gender groups.

The analysis of the linear regression model (see Table 1) showed that it was statistically significant $(\mathrm{p}=0.001)$ and the coefficient of determination $-\mathrm{R} 2=0.317<0.25$ - indicated that the model was suitable. Apparently, $32 \%$ of communication failures were determined by the formation of negative opinions and the nature of work.

Table 1. Coefficients of the Regression Model

\begin{tabular}{|c|c|c|c|c|c|}
\hline \multirow[t]{2}{*}{ MODEL } & \multicolumn{2}{|c|}{$\begin{array}{c}\text { UNSTANDARDIZED } \\
\text { COEFFICIENTS } \\
\end{array}$} & \multirow{2}{*}{$\begin{array}{c}\text { STANDARDIZED } \\
\text { COEFFICIENTS } \\
\text { Beta }\end{array}$} & \multirow[t]{2}{*}{$t$. } & \multirow[t]{2}{*}{ Sig. } \\
\hline & $B$ & Std. Error & & & \\
\hline Constant & 15,266 & 4,340 & & 3.518 & 0.001 \\
\hline $\begin{array}{l}\text { Forming negative opinions and } \\
\text { work tasks }\end{array}$ & 0.429 & 0.094 & 0.563 & 4.571 & 0.000 \\
\hline
\end{tabular}

Source: Authors.

The model is expressed by the following equation: $y=15.266+0.429 x$.

15.266 is a constant, $\mathrm{b} 1=0.429$ is a coefficient, $\mathrm{x}$ represents the formation of a negative opinion and the nature of work, and y indicates communication failures among employees.

According to this model, reducing the number of victims who experience mobbing through the formation of negative opinions and the nature of work, i.e., attacks on reputation and employees during assignments, by one point, communication failures among employees would be reduced by about half a point $(0.43)$. The study also found that reputation attacks were most often manifested through unfair evaluation of work, false rumours about the victim and doubts about their proposed solutions, while the assignment subscale was dominated by tasks that exceeded capabilities and competencies of the victim who would constantly receive new tasks. Therefore, if those negative 
actions were controlled, the number of communication failures among employees would be reduced as a result.

\section{Discussion}

The aim of the research was to identify whether mobbing was present in the Ministry of National Defence of Lithuania and to determine its manifestation in organisations through employees' relationships. Data obtained during the study partially confirm the results of other research. The main hypothesis that mobbing exists in the MND was confirmed, but the number of employees experiencing mobbing $(23.4 \%)$ is in line with the general trend found by other researchers: Balčiūnienè and Rumšaitè (2016) identified that $29 \%$ of respondents experienced mobbing, while Pajarskienè et al . (2012) identified 25.4\%, and Vveinhardt and Andriukaitienè (2015) found 24.6\% of those affected.

The research data showed statistically significant links between communication and isolation, communication and reputation, communication and assignments, isolation and reputation, isolation and assignments, reputation and assignments, reputation and harm, assignments and health, which confirms hypotheses H1-H8. These findings are confirmed by Notelaers et al. (2018) who state that employees suffering from mobbing experience social isolation, lower job satisfaction and deteriorating health; as well as by Agervold (2007) who maintains that a higher level of workplace mobbing is related to pressure and high requirements at work, role conflicts and a poor social climate. In summary, it may be stated that workplace bullying is a problem in the MND and the existing prevention and intervention measures are not effective. However, based on previous theoretical research (Prakapienè, Skurdienè, 2019), it may be maintained that the concept of workplace mobbing is not determined and legally validated in the MND and in the system of National Defence. In addition, there are no comprehensively developed and clearly determined tools and decision-making procedures addressing this issue. Separate measures, such as procedures for dealing with conflicts and arguments or misconduct etc., do not provide a comprehensive solution to the problem and do not eliminate its fundamental causes.

It was found that the frequency of mobbing depends on the gender (women in the MND experience mobbing more often than men) and its employees experience mobbing regardless of their length of service. These findings contradict the claims of Vveinhardt and Žukauskas (2012) and Zachariadou et al. (2018), who maintain that those most frequently experiencing workplace mobbing are respondents with service length between 4 and 7 years. Also, no manifestation of vertical mobbing, when a manager become an aggressor, was determined within the organisation (Einarsen et al., 2004; Vveinhardt and Žukauskas, 2012). This peculiar feature and the hypothesis being not confirmed is likely to be due the fact that there is a high staff turnover in the MND and the organisations under it. However, this requires more in-depth research.

The results of the study revealed that horizontal mobbing (from one or more colleagues) is more likely to exist in the MND. Victims often experience mobbing through verbal forms of communication, such as criticism of their work results, false rumours, unfair evaluation of their work, disrespectful communication, etc. It may be assumed that this is related to the fact that in statutory organisations positions held are of high importance and they are often achieved through the principle of competition or depend on the military rank. The presumption that victims are not ridiculed because of their social status or religious views and never receive offensive tasks was not confirmed either. However, deeper decision-making is required by the fact that victims are reluctant to solve the problem, limiting themselves to conversations with relatives and colleagues. Only $16 \%$ of the respondents had informed the manager. They also felt that the organization had not taken any action to avoid bullying and harassment and most respondents felt that the abuser had gone unpunished or had been unaware of the punishment. Thus, conflicts of misconduct in the MND seem to be solved reluctantly, focusing more on local measures, such as discussions with colleagues to avoid publicity. This is basically in line with the findings of Balčiūnienè and Rumšaitė (2016), who highlight that employees are reluctant to publicly deal with their problems and prefer to address them on a personal 
level. In other words, this corresponds to the first stage of workplace mobbing, when decision-making depends on the personal features of the victim and does not involve the organisation.

We are convinced that in pursuit of more in-depth and accurate research, it should be expanded and carried out across the entire Lithuanian army. It is likely that the specific features of the military organisation would allow for a more accurate identification and verification of Sperry's (2009) assumption that workplace mobbing is observed in large organisations with an organisational structure of hierarchical levels. The present research confirmed this assumption only in part, presumably due to research limitations because in this research statutory respondents accounted for a smaller share of all possible research subjects.

\section{Conclusions}

1. The empirical study confirmed the main hypothesis that mobbing exists in the MND and its institutions. The number of employees $(23.4 \%)$ that have experienced mobbing corresponds to the general trend established by previous research.

2. The research showed that women are more likely to experience mobbing than men. Employees, regardless of their length of service, are most often attacked by one or more colleagues using verbal forms of communication (yelling, constant criticism of their work results, false rumours, unfair evaluation of their work, etc.).

3. Respondents who had experienced mobbing were reluctant to solve the problem, limiting themselves to conversations with their relatives and colleagues. In their opinion, the organization had never taken any action to avoid bullying and harassment and the abuser had gone unpunished. Furthermore, some respondents did not know anything about what action the management had taken or the consequences for the abuser. This indicates that the MND and its institutions may have organizational communication problems in solving mobbing problems.

4. The analysis of the questions aimed at establishing the intervention and prevention system in the MND and its institutions showed that their intervention and prevention measures may be ineffective. Mobbing conflicts are solved reluctantly (most often without taking any action), focusing on local measures (discussions with colleagues).

5. The confirmed hypotheses showed a statistically significant relationship among communication, isolation, reputation, assignments, health and harm subscales, and the linear regression model provided an opportunity to reduce the number of communication failures among employees by reducing the formation of negative opinions and the nature of work.

6. The analysis of the opportunities to reduce workplace mobbing in the MND revealed that a positive result may be achieved through developing the following areas of organisational management: improving communication, increasing trust in employees, assigning tasks based on employees' competences and exercising fair assessment.

\section{References}

1. Agervold, M. (2009). The significance of organizational factors for the incidence of bullying. Scandinavian Journal of Psychology, 50, p.267-276.

2. Akter, J. (2019). The Psychological Effects of Workplace Bullying among Bangladeshi Women. EC Psychology and Psychiatry, 8 (12), p. 01-08.

3. Astrauskaitè, M., Kern, M. R. (2013). Patyčios darbe: sampratos, paplitimo, pasekmių ir priežasčių analizė. Visuomenés sveikata, 4 (63), p. 20-29.

4. Balčiūnienė, J., Rumšaitè, A. (2016). Mobingas: identifikavimas, valdymas ir prevencija. Žmogiškuju ištekliu valdymo aktualijos, p. 29-35.

5. Bekešienè, S. (2015). Knyga duomenu analizès SPSS pagrindai. Vilnius: Generolo Jono Žemaičio Lietuvo skaro akademija.

6. Bryman, A. (2016). Social Research Methods (5 $5^{\text {th }}$ ed.). Oxford University Press.

7. Čekanavičius, V., Murauskas, G. (2014). Taikomoji regresiné analizé socialiniuose moksluose. Vilnius: Vilniaus universiteto leidykla. 
8. Duffy, M., Sperry, L. (2014). Overcoming Mobbing-A Recovery Guide for Workplace Aggression and Bullying, Oxford University Press.

9. Feijó, F.R., Gräf, D.D., Pearce, N., Fassa, A.G. (2019). Risk Factors for Workplace Bullying: A Systematic Review. Public Health, 16, p. 1-25.

10. Galletta D., Confuorto, M., Improta, G., Marcelli, V. (2019). The assessment of mobbing damage: When the psychological pain becomes physical. Journal of Forensic Science \& Criminology, 7(1), p.1-4.

11. Georgakopoulos, A., Kelly, M. P. (2017). Tackling workplace bullying: A scholarship of engagement study of workplace wellness as a system. International Journal of Workplace Health Management, 10(6), p. 450-474.

12. Góralewska-Słońska, A. (2019). Experiencing mobbing at workplace facing psychological gender and occupational burnout. Management, 23(1), p. 156-173.

13. Guglielmi, D.; Mazzetti, G.; Villano, P.; Cantisano, G.T. (2018). The impact of perceived effort—Reward imbalance on workplace bullying: Also a matter of organizational identification. Psychology, Health and Medicine, 23, p. 511516.

14. Hassard, J., Teoh, K. R. H., Visockaite, G., Dewe, P., Cox, T. (2018). The financial burden of psychosocial workplace aggression: A systematic review of cost-of-illness studies. Work \& Stress, 32(1), p. 6-32.

15. Kardelis, K. (2016). Moksliniu tyrimu metodologija ir metodai. Vilnius: Mokslo ir enciklopedijų leidybos centras.

16. Kowal, J., Gwiazda-Sawicka, G. (2018). Mobbing as a problem in management ethics. Annales. Ethics in Economic Life, 21 (5), p. 131-145.

17. Leymann, H. (1996). The Content and Development of Mobbing at Work. European Journal of Work and Organizational Psichology, 5 (2), p. 165-184

18. Mileta, T. (2012). Mobbing: the incidence of mobbing activities and differences regarding workplace and gender. Megatrend Review, 9(1), p. 243-252.

19. Mujtaba, B.G., Senathip, T. (2020). Workplace Mobbing and the Role of Human Resources Management. Business Ethics and Leadership, 4(1), p. 17-34.

20. Nielsen, M. B., Glasø, L., Einarsen, S. (2017). Exposure to workplace harassment and the Five Factor Model of personality: A meta-analysis. Personality and Individual Differences, 104, p. 195-206.

21. Nielsen, M. B., Nielsen, G. H., Notelaers, G., Einarsen, S. (2015). Workplace bullying and suicidal ideation: A 3 wave longitudinal Norwegian study. American Journal of Public Health, 105(11), p. 23-28.

22. Notelaers, G., Van der Heijden, B., Hoel, H., Einarsen, S. (2018). Measuring bullying at work with the short-negative acts questionnaire: identification of targets and criterion validity. Work and Stress, 33(1), p. 58-75.

23. Pajarskienè, B., Vèbraite,, I., Andruškienè, J., Jurgutis, A. (2012). Ujimo / priekabiavimo dažnis Vilniaus ir Klaipėdos darbo vietose pagal ekonomines veiklas ir profesijas. Visuomenés sveikata, 2(57), p. 57-69.

24. Pakalniškienè, V. (2012). Tyrimo ir ịvertinimo priemoniu patikimumo ir validumo nustatymas: metodine priemoné. Vilnius: Vilniaus universiteto leidykla.

25. Prakapienè, D., Skurdenienè, N. (2019). Mobbing in a statutory organization : theoretical. In Proceedings of 175th ISERD International Conference, Tallinn, Estonia, 14th -15th October, p. 9-14.

26. Salin, D. (2015). Risk factors of workplace bullying for men and women: The role of the psychosocial and physical work environment. Scandinavian Journal of Psychology, 56(1), p. 69-77.

27. Salin, D., Cowan, R., Adewumi, O., Apospori, E., Bochantin, J., D’Cruz, P., Djurkovic, N., Durniat, K., Escartin, J., Guo, J., I6ik, I., Koeszegi S.T., McCormack, D., Monserrat S.I., Zedlacher, E. (2019). Workplace bullying across the globe: a cross-cultural comparison. Personnel Review, 48 (1), p. 204-219.

28. Samnani, A. K., Singh, P. (2016). Workplace Bullying: Considering the Interaction between Individual and Work Environment. Journal of Business Ethics, 139(3), p. 537-549.

29. Spagnoli, P., Balducci, C. (2017). Do high workload and job insecurity predict workplace bullying after organizational change? International Journal of Workplace Health Management, 10(1), p. 2-12.

30. Sperry, L., Duffy, M. (2009). Workplace mobbing: Family dynamics and therapeutic considerations. American Journal of Family Therapy, 37(5), p. 433-442.

31. Sroka, W., Vveinhardt, J. (2020). Nepotism and favouritism: how harmful are these phenomena? Forum Scientiae Oeconomia, 8 (2), p. 79-91.

32. Takaki, J., Tsutsumi, A., Fujii, Y., Taniguchi, T., Hirokawa, K., Hibino, Y., Lemmer, R.J., Nashiwa, H., Wang H., Ogino, K. (2010). Assessment of workplace bullying and harassment: Reliability and validity of a Japanese version of the negative acts questionnaire. Journal of Occupational Health, 52(1), p. 74-81.

33. Vveinhardt, J. (2012). Mobingo nuostolių mažinimas koreguojant organizacijų etikos kodeksus. Management Theory and Studies for Rural Business and Infrastructure Development, 2(31), p. 145-151.

34. Vveinhardt, J. (2011). Mobingo pasekmių individui, organizacijai, sociumui daugialypiškumo modeliavimas ir iveikimo prielaidos. Ekonomika ir vadyba: aktualijos ir perspektyvos, 2, p. 15-24.

35. Vveinhardt, J., Andriukaitienè, R. (2015). Questionnaire verification of prevention of mobbing/bullying as a psychosocial stressor when implementing CSR. Problems and Perspectives in Management, 13(2), p. 57-70.

36. Vveinhardt, J., Fominiene, V. B., Jeseviciute-Ufartiene, L. (2018). Bullying and Harassment as Antisocial Behaviours: Socio-Economic Aspects of Their Impact Assessment. Inžinerinė Ekonomika-Engineering Economics, 29(5), p. 548-558. 
37. Vveinhardt, J., Majauskiene, D., Valanciene, D. (2020). Does perceived stress and workplace bullying alter employees' moral decision-making? Gender-related differences. Transformations in Business \& Economics, 19(1), p. 323-342.

38. Vveinhardt, J., Streimikiene, D. (2015). The questionnaire for diagnosing mobbing in employees' relationships. Economic Research-Ekonomska Istrazivanja, 28(1), p. 441-466.

39. Vveinhardt, J., Žukauskas, P. (2012). Mobingas darbuotojų santykiuose: individas, organizacija, sociumas. Kaunas: Vytauto Didžiojo universiteto leidykla.

40. Vveinhardt, J., Žukauskas, P. (2010). Mobingo specifiškumas: lietuviškojo mentaliteto bruožai. Management Theory \& Studies for Rural Business \& Infrastructure Development, 20 (1), p. 1-9.

41. Zachariadou, T., Zannetos, S., Chira, S. E., Gregoriou, S., Pavlakis, A. (2018). Prevalence and Forms of Workplace Bullying among Health-care Professionals in Cyprus: Greek Version of "Leymann Inventory of Psychological Terror" Instrument. Safety and Health at Work, 9, p. 339-346.

42. Zaitseva, V., Chaudat, P. (2016). Les déterminants organisationnels du harcèlement moral : une analyse d'une revue actualisée de littérature. Revue Management \& Avenir, 84, p. 115-134.

43. Zapf, D., Einarsen, S. (2011). Individual antecedents of bullying: Victims and Perpetrators. In Einarsen, S., Hoel, H., Zapf, D., Cooper, C. (eds.), Bullying and Harassment in the Workplace: Developments in Theory, Research, and Practice. 2nd ed. London: Taylor \& Francis Group, p. 177-200.

Nijolè Skurdenienè, Dalia Prakapienè

\section{Mobingo raiška viešajame sektoriuje: Lietuvos respublikos krašto apsaugos ministerijos ir jai priklausančių institucijų atvejis}

\section{Anotacija}

Vienas iš organizacijos sėkmès elementų yra organizacinè kultūra, kuri pasireiškia per darbuotojų gerovès kūrimą, vertybių sistemą ir pan. Šiame kontekste mobingas yra vienas iš negatyvių reiškinių, suprantamas kaip individų darbe patiriama psichologine ịtampa dèl kito asmens (-u) taikomų neigiamų poveikio priemonių, sukeliančių neigiamas pasekmes asmeniui, organizacijai ir visuomenei. Atsižvelgiant ị tai, kad mobingo raiška statutinèse arba su jų veikla susijusiose organizacijose iš esmès nebuvo tirta, šiuo straipsniu siekiama atskleisti mobingo raiškos Lietuvos respublikos krašto apsaugos ministerijoje ir jai priklausančiose institucijose ypatumus per organizacijos aplinką bei darbuotojo ir darbdavio santykius. Tyrime dalyvavo 201 respondentas. Nustatyta, kad Krašto apsaugos ministerijoje ir jai priklausančiose institucijose mobingas egzistuoja, tačiau mobingą patiriančių darbuotojų skaičius atitinka bendrą mokslininkų tyrimais nustatytą tendenciją. Tyrimo rezultatai atskleidè, kad mobingo raiška nepriklauso nuo darbuotojo darbo stažo; mobingas dažniausiai pasireiškia vartojant verbalines komunikavimo formas, o moterys mobingą patiria dažniau nei vyrai. Galima teigti, kad mobingo prevencija tirtose institucijose yra silpna, mobingo konfliktai sprendžiami vangiai, susikoncentruojant tik ị lokalines priemones.

Nijole Skurdeniene - Senior Specialist of Personnel and Coordination Section, Office of the Lithuanian Armed Forces.

E-mail: nijole.skurdeniene@gmail.com

Dalia Prakapiene - doctor of Social Sciences, associate professor at the General Jonas Žemaitis Military Academy of Lithuania.

E-mail: $\underline{\text { dalia.prakapiene @ lka.lt }}$ 
Nijole Skurdeniene - Lietuvos kariuomenès kanceliarijos Personalo ir koordinavimo skyriaus personalo vyriausioji specialistè.

El. paštas: nijole.skurdeniene@gmail.com

Dalia Prakapiené - socialinių mokslų daktarè, Generolo Jono Žemaičio Lietuvos karo akademijos docentè.

El. paštas: dalia.prakapiene@1ka.lt

This article is an Open Access article distributed under the terms and conditions of the Creative Commons Attribution 4.0 (CC BY 4.0) License (http://creativecommons.org/licenses/by/4.0/ ). 